\title{
POPULATION DENSITY OF SOIL MITES AND CERTAIN SUCKING PESTS AND AVAILABILITY OF NPK IN SOYBEAN PLANT AND SOIL AS INFLUENCED BY ORGANIC MANURES AND MINERAL FERTILIZERS
}

Saadoon, Sohair E.'; R.I.E. Magouz'; Ahlam A. Younes ${ }^{1}$ and S.A. El-Saady ${ }^{2}$

1 Plant Protection Res. Inst., Agric. Res. Center, Dokki, Giza, Egypt

2 Soil, Water and Environment Research Inst., Agric. Res. Center, Dokki, Giza, Egypt.

\begin{abstract}
This experiment was carried out at Sakha Agricultural Research Station Farm in 2007 season to find out the effect of organic manures and mineral fertilizers on the population density of mites and some sucking insects. Also, the availability of NPK and organic matter was investigated. The spider mite, Tetranychus cucurbitacearum (Sayed) exhibited the highest population in plants treated with poultry manure $>$ urea $>$ sheep manure $>$ ammonium nitrate $>$ pigeon refuse. The whitefly populations was highest on plants treated with mineral fertilizers than on those treated with organic manures while the contrast was found in the insect predators population. Aphid population was highest in case of urea and sheep manure, but lowest in pigeon refuse. The thrips numbers were highest on plants treated with poultry manure $>$ pigeon refuse $>$ urea $>$ ammonium nitrate $>$ sheep manure. Both nitrogen and potassium were more available in soybean plants treated with organic manure than those treated with mineral fertilizers. Regarding soil mite groups, soil of poultry manure exhibited the highest population density of mites, followed by pigeon refuse and sheep manure, while the lowest mite populations were detected in plots treated with mineral fertilizers. Cryptostigmata usually exhibited the highest percentages among mite groups followed by Heterostigmata, Prostigmata, Mesostigmata and Astigmata. The highest available $\mathrm{N}$ and organic matter were detected in the soils treated with pigeon refuse, while the highest levels of $P$ and $K$ were found in soils treated with sheep manure.
\end{abstract}

\section{INTRODUCTION}

The production of soybean, Glycine max Merr., which is a good source of protein to the soil and for human consumption and is a rich food for livestock, has received special attention in Egypt during the last decades. So, the Ministry of Agriculture plans to expand soybean cultivated area to meet a part of the national requirement of oil, protein and animal feed. Losses of nitrogen fertilizers are not only impacts to the environment but also are great economic losses. Therefore, efforts should be devoted to avoid or minimize these losses. Amberger (1993) reported that in soils of high pH, the oxidation of ammonium to nitrite precedes faster than the next step to nitrate, therefore, higher concentration of the toxic nitrite can be accumulated. Nitrates are very soluble, they can be leached out easily and pollute ground drinking water. Nitrate is estimated as a hazard to human health, after reduction to nitrite in the stomach it may be carcenogenic. With regard to organic fertilization 


\section{Saadoon, Sohair E. et al.}

recently on the way of clean agriculture with minimum pollution effects, the use of natural materials such as organic manures is recommended to substitute the chemical fertilizers (Khalil et al., 2000). Amendment of the soil with organic manure improves their physical, chemical and biological properties and hence the availability of plant nutrients (El-Fouly et al., 1997). Hamissa and Abdel-Salam (1999) reported that the most organic manures are used primarily as a source of nitrogen, however they also contain many microelements [El-Shazly and El-Masri (2002)].

The levels of nitrogen, phosphorus and potassium differ from location to another according to the soil fertility (Harmati, 1991 and Chougule et al., 1993). The balance between these nutrient elements can change the physiology of the plant as a food for insect species (Coaker, 1987). Several mite species play an important role, by direct or indirect ways, in soil fertility. It has been generally assumed that some prostigmatids and mesostigmatids are predacious, while, cryptostigmatids and astigmatids are fungi vorous and saprophagous (Luxton, 1972 and Acki, 1973). Some numbers of the Tarsonimina may be either parasites or predators, phytophagous and fungivorous, living in soil, litter or organic manure. Certain species cause diseases for invertebrates and vertebrates, in addition to transmission of plant diseases. Therefore, this work was undertaken to study the effect of three organic manures and two mineral fertilizers on the population density of soil mites, certain sucking pests and some characteristics of soil and soybean plants at Kafr El-Sheikh Governorate.

\section{MATERIALS AND METHODS}

The present experiment was carried out at Sakha Agricultural Research Station Farm, Kafr El-sheikh during 2007 season. The experimental area was divided into 24 plots, each of $1 / 100$ feddan. Every treatment was replicated four times in a completely randomized block design. Soybean plants were sown by late May. The normal agricultural practices were conducted during the season without any pesticidal treatments. Organic manures i.e. sheep manure, poultry manure and pigeon refuse (Table 1) were added to the soil with rates of $20 \mathrm{~m}^{3} / \mathrm{fed}$. before sowing, while chemical fertilizers applied as ammonium nitrate $(33.5 \% \mathrm{~N})$ and urea $(46.0 \% \mathrm{~N})$ were added in two equal doses; the first before the first irrigation and the second in the following irrigation with recommended doses of $30 \mathrm{~kg}$ each. Weekly samples of ten soybean leaflets were collected at random from each plot. The collected leaflets were kept in paper bags and transferred to the laboratory to count mobile stages spider mite of Tetranychus cucurbitacearum (Sayed). Thrips, Thrips tabaci (Lind.) Aphids, Aphis gossypii (Glover) immature stages of whitefly, Bemisia tabaci (Genn) and associated predators were counted by the aid of stereoscopic binocular microscope. The data obtained were statistically analyzed using Duncan's multiple range test (1955). Other samples of soybean leaflets were collected weekly at random from each plot to determine the concentrations of $\mathrm{N}, \mathrm{P}$ and $\mathrm{K}$ as following: ten soybean leaflets were dried at $70^{\circ} \mathrm{C}$ for 12 hours, weighed and ground in a Wiley 
stainless steel mill. Proteins of each plant materials $(0.29 \mathrm{~g})$ were digested in $5 \mathrm{ml}$ of $\mathrm{H}_{2} \mathrm{SO}_{4}$ and $1 \mathrm{ml}$ perchloric acid in a conical flask as described by Chapman and Pratt (1961).

The digested materials were distilled by microkejeldahl method and nitrogen content (\%) of distillate was determined according to Page (1982). The total phosphorus content of leaves was determined. The digested materials were diluted in measuring flasks and the phosphorus content $(\%)$ of samples was determined colorimetically according to the method described by Snell and Snell (1967). The total potassium was determined using flame photometer according to the method described by Jackson (1958).

Soil samples were taken periodically every week from various parts of soybean field. The samples represented the arable layer of the surface to the depth of $10 \mathrm{~cm}$ under soybean plants since it was found that soil acari seemed to be more abundant in the surface stratum, 0-10 cm (Abo-Korah et al., 1982).

Soil core were taken with an iron sampler volume $1000 \mathrm{cc}$. On the other hand, the population densities of soil mites of the five suborders, Heterostigmata, Cryptostigmata, Mesostigmata, Astigmata and Prostigmata were counted. Mites were extracted using the modified Tullgren funnels for two days (El-Badry 1973 and Abo-Korah, 1977) to insure complete extraction of mites. The extracted mites were kept in $70 \%$ ethyl alcohol and were examined for identification under stereoscopic binoclar microscope for the five systematic acari groups: Heterostigmata, progstigamta, Cryptostigmata, Astigmata and Mesostigmata according to Lindquist et al. (1979).

1. Chemical analysis of soils:

Soil samples were air dried, crushed and passed through $2.00 \mathrm{~mm}$ sieve for the following chemical analysis:

a. Available phosphorus of soil and different organic manures were determined by extraction with $0.5 \mathrm{~N}$ sodium bicarbonate according to Olsen et al. (1954) and determined colorimetrically by ascorbic acid method according to Schouwenbury Van and Walinge (1967).

b. Available potassium of soil and organic manure were extracted by ammonium acetate and determined by flame photometer according to Page (1982).

c. Available nitrogen was extracted by $1 \% \mathrm{~K}_{2} \mathrm{SO}_{4}$ and determined using conventional method of micro-kjeldahl, Page (1982).

d. Soil reaction $(\mathrm{pH})$ was determined in 1-2.5 soil-water suspension using Bechman pH meter according to Page (1982).

Composite surface soil samples $(0-30 \mathrm{~cm})$ were collected, air dried and passed in a $2 \mathrm{~mm}$ sieve thoroughly. Mixed samples were analyzed for $\mathrm{N}$, $\mathrm{P}$ and $\mathrm{K}$ contents according to Page (1982). (1955).

The data were analyzed according to Duncan's multiple range test

\section{Chemical analysis of plant:}

Samples of leaflets of soybean plants were dried at $70^{\circ} \mathrm{C}$ for 12 hours, weighed and ground in a Wiley stainless steel mill. Proteins of each 
plant material $(0.2 \mathrm{~g})$ were digested in $5 \mathrm{ml}$ of $\mathrm{H}_{2} \mathrm{SO}_{4}$ and $1 \mathrm{ml}$ perchloric acid in a conical flaks as described by Chapman and Pratt (1961).

a. The digested materials were distilled by microkjeldahl method and nitrogen content (\%) of distillate was determined according to Page (1982).

b. Determination of the total phosphorus content of soybean plant. The digested materials were diluted in measuring flasks and the phosphorus content (\%) of samples was determined colorimetriclaly according to the method described by Snell and Snell (1967).

c. The total potassium was determined using flamephotometer according to the method described by Jackson (1958).

Table (1): Some characteristics of the tested organic manures.

\begin{tabular}{|c|c|c|c|c|c|c|c|}
\hline Organic manure & $\mathbf{N} \%$ & $\mathbf{P} \%$ & $\mathbf{K} \%$ & $\mathbf{C} \%$ & $\mathbf{O M} \%$ & $\mathbf{C} / \mathbf{N}$ & $\mathbf{p H}$ \\
\hline Poultry manure & 3.36 & 0.441 & 1.52 & 40.70 & 70.10 & 12.1 & 6.30 \\
\hline Sheep manure & 1.87 & 1.30 & 1.94 & 54.23 & 93.28 & 29.1 & 6.60 \\
\hline Pigeon refuse & 3.80 & 1.80 & 2.10 & 33.00 & 57.00 & 8.68 & 6.70 \\
\hline
\end{tabular}

OM: Organic matter.

\section{RESULTS AND DISCUSSION}

1. Effect of some organic manures and mineral nitrogen fertilizers on certain sucking pests and associated predators:

Effect of organic manure and mineral nitrogen fertilizers on certain sucking pests and associated predators is presented in Table (2). The data show the mean numbers of the sucking pests and associated predators collected from plants treated with different types of fertilizers. The data revealed that the two spotted spider mite, Tetranychus cucurbitacearum (Sayed) exhibited the highest number (11.45/10 leaflets) in poultry manure, followed by that in urea (10.05), sheep manure and ammonium nitrate (9.48 each), pigeon refuse (8.38 individuals/10 leaflets) and then control (7.45).

Table (2): Mean number of some sucking pests and associated predators on soybean plants treated with different types of fertilizers during 2007 season.

\begin{tabular}{|l|c|c|c|c|c|c|}
\hline \multirow{2}{*}{ Arthorpod } & \multicolumn{5}{|c|}{ Mean number /10 leaflets at different types of fertilizers } \\
\cline { 2 - 7 } & $\begin{array}{c}\text { Sheep } \\
\text { manure }\end{array}$ & $\begin{array}{c}\text { Pigeon } \\
\text { refuse }\end{array}$ & $\begin{array}{c}\text { Poultry } \\
\text { manure }\end{array}$ & $\begin{array}{c}\text { Ammonium } \\
\text { nitrate }\end{array}$ & Urea & Control \\
\hline T. cucurbitacearum & $9.48 \mathrm{bc}$ & $8.38 \mathrm{~cd}$ & $11.45 \mathrm{a}$ & $9.48 \mathrm{bc}$ & $10.05 \mathrm{ab}$ & $7.45 \mathrm{~d}$ \\
\hline Bemisia tabaci & $2.75 \mathrm{~b}$ & $3.18 \mathrm{~b}$ & $3.20 \mathrm{~b}$ & $4.0 \mathrm{a}$ & $4.05 \mathrm{a}$ & $3.40 \mathrm{ab}$ \\
\hline Aphis gossypii & $0.58 \mathrm{a}$ & $0.05 \mathrm{~b}$ & $0.20 \mathrm{~b}$ & $0.18 \mathrm{~b}$ & $0.68 \mathrm{a}$ & $0.05 \mathrm{~b}$ \\
\hline Thrips tabaci & $1.48 \mathrm{c}$ & $2.13 \mathrm{~b}$ & $2.83 \mathrm{a}$ & $1.70 \mathrm{bc}$ & $1.83 \mathrm{bc}$ & $1.53 \mathrm{c}$ \\
\hline Predators & $5.38 \mathrm{a}$ & $5.03 \mathrm{a}$ & $3.38 \mathrm{~b}$ & $2.63 \mathrm{c}$ & $2.23 \mathrm{c}$ & $0.90 \mathrm{~d}$ \\
\hline Total & 19.67 & 18.77 & 21.06 & 17.99 & 18.84 & 13.33 \\
\hline
\end{tabular}

In a row, means followed by the same letter are not significantly different at the $5 \%$ level.

The numbers of whitely were higher in mineral fertilizers than in organic ones. Aphids were highest in urea (0.68) and sheep manure (0.58), 
but lowest in pigeon refuse and control (0.05 each). Thrips numbers were highest in poultry manure (2.83) and pigeon refuse (2.13 indiv/10 leaflets). Obviously, the predators were more occurring in organic manure (3.38-5.38 indiv/10 leaflets) than in mineral fertilizers. In general, poultry manure had the highest number of arthropods (21.06 indiv/10 leaflets), followed by sheep manure (19.67), urea (18.84), pigeon refuse (18.77), ammonium nitrate (17.99) and then control (13.33 indiv/10 leaflets).

\section{Macronutrient contents of soybean:}

Data demonstrated in Table (3) show that the N, P and K contents of soybean leaves in mature plants were highly significant as affected by types of the organic manures as well as mineral fertilizers. Data show that the N, P and $\mathrm{K}$ content of soybean leaves were higher in organic manures and mineral fertilizers than in the control. These increases adopted following decreasing order:

For N: Sheep manure > poultry manure $>$ pigeon refuse $>$ urea $>$ ammonium nitrate $>$ control.

For P: Urea $>$ poultry manure $\geq$ pigeon refuse $>$ sheep manure > ammonium nitrate $>$ control.

For K: Sheep manure $>$ poultry manure $>$ pigeon refuse $>$ ammonium nitrate $>$ urea $>$ control. Similar trends were obtained by Abd-Allah (1998), Saber (2000), Talha 2003, Abou El-Khir et al. (2004).

Table (3): Effect of application of organic manures and mineral nitrogen fertilizers on the availability of NPK and yield of soybean.

\begin{tabular}{|c|c|c|c|c|c|c|}
\hline Macro-element & $\begin{array}{c}\text { Sheep } \\
\text { manure }\end{array}$ & $\begin{array}{c}\text { Pigeon } \\
\text { refuse }\end{array}$ & $\begin{array}{c}\text { Poultry } \\
\text { manure }\end{array}$ & $\begin{array}{c}\text { Ammonium } \\
\text { nitrate }\end{array}$ & Urea & Control \\
\hline $\mathrm{N}$ & $3.22 \mathrm{a}$ & $2.64 \mathrm{~b}$ & $2.74 \mathrm{~b}$ & $2.11 \mathrm{c}$ & $2.17 \mathrm{c}$ & $1.96 \mathrm{c}$ \\
\hline $\mathrm{P}$ & $0.67 \mathrm{abc}$ & $0.73 \mathrm{ab}$ & $0.73 \mathrm{ab}$ & $0.56 \mathrm{bc}$ & $0.78 \mathrm{a}$ & $0.51 \mathrm{c}$ \\
\hline $\mathrm{K}$ & $1.61 \mathrm{a}$ & $1.28 \mathrm{~b}$ & $1.30 \mathrm{~b}$ & $1.27 \mathrm{~b}$ & $1.20 \mathrm{bc}$ & $1.07 \mathrm{c}$ \\
\hline Weight of 1000 seeds $(\mathrm{g})$ & 184.8 & 193.1 & 154.4 & 152.0 & 194.3 & 144.4 \\
\hline
\end{tabular}

The weight of 1000 soybean seeds was highest in plots fertilized with urea $(194.3 \mathrm{~g})$, followed by that in plots of pigeon refuse $(193.1 \mathrm{~g})$, and sheep manure $(184.8 \mathrm{~g})$. However, the lowest seed weight was in control plots $(144.4 \mathrm{~g})$ and in plots treated with ammonium nitrate $(152.0 \mathrm{~g})$.

3. Population of mites in soils treated with different types of fertilizers:

Data in Table (4) show the numbers of soil mites in soybean plots treated with different types of fertilizers, for nine successive weeks of 2007 season. In plots of sheep manure, the numbers was high in the first week of examination (6800 individuals $/ \mathrm{m}^{3}$ ), and then the numbers fluctuated to reach the maximum (11300 indiv) in the $8^{\text {th }}$ week. The peak numbers of pigeon refuse, poultry manure, ammonium nitrate and urea were recorded in $7^{\text {th }}, 7^{\text {th }}$, $5^{\text {th }}, 8^{\text {th }}$ weeks, respectively. As for control plots, the highest number of mites was recorded in the seventh week $\left(13500 \mathrm{indiv} / \mathrm{m}^{3}\right)$, while the lowest was recorded in the ninth week (1100 indiv $\left./ \mathrm{m}^{3}\right)$. 
In general, the greatest number $\left(62100 \mathrm{indiv} / \mathrm{m}^{3}\right)$ throughout the soybean season was recorded in plots treated with poultry manure, followed by that of pigeon refuse (55400), sheep manure (49700), ammonium nitrate (40700), urea (38800) and then control plot (37900 indiv/ $\left./ \mathrm{m}^{3}\right)$.

Table (4): Numbers of soil mite groups under soybean plants treated with different types of fertilizers during 2007 season.

\begin{tabular}{|l|c|c|c|c|c|c|c|c|c|c|}
\hline \multicolumn{1}{|c|}{ Treatment } & $\begin{array}{c}\mathbf{w e e k} \\
\text { ween manure }\end{array}$ & $\mathbf{2}$ & $\mathbf{3}$ & $\mathbf{4}$ & $\mathbf{5}$ & $\mathbf{6}$ & $\mathbf{7}$ & $\mathbf{8}$ & $\mathbf{9}$ & Total \\
\hline Sheep mo0 & 3400 & 5800 & 3800 & 6600 & 3600 & 2900 & 11300 & 5500 & 49700 \\
Pigeon refuse & 5300 & 2300 & 5000 & 4100 & 4900 & 7900 & 11700 & 10300 & 3900 & 55400 \\
Poultry manure & 5500 & 6300 & 3400 & 2900 & 9000 & 8700 & 17800 & 5700 & 2800 & 62100 \\
Ammonium nitrate & 1800 & 3700 & 3200 & 3200 & 12700 & 2500 & 6300 & 3300 & 4000 & 40700 \\
Urea & 3400 & 4600 & 3000 & 5400 & 6700 & 3000 & 5200 & 6000 & 1500 & 38800 \\
Control & 3300 & 2300 & 2200 & 3300 & 5200 & 3600 & 13500 & 3400 & 1100 & 37900 \\
\hline Total & & & & & & & & & & 284600 \\
\hline
\end{tabular}

The results agree with those obtained by Abd-Alla (1974) who reported that fertilization generally causes a positive effect on the population density of soil arthropods. Cow manure was found to promote high numbers, better than nitrate and phosphate. Abo-Korah et al. (1984) found that nitrogenous fertilizers had a significant effect in increasing the population density of different Acari groups. In treatments of farmyard manure plus nitrogenous fertilizer, Tarsoneminae occurred in great abundance (31\%), followed by Cryptostigmata (31\%), Mesostigmata (14\%), Astigmata (13\%) and Prostigmata (11\%). Saleh and Tadros (1985) found that application of urea at the recommended rates in vegetable farms gave a rapid decrease in soil arthropods, especially Cryptostigmata mites, followed by an increase after a short-period. The decrease of soil arthropods that happened when applying chemical nutrients may be attributed to deep-down migration of organisms to lower soil strata. The observations of the same authors indicated that adding high levels of cattle manure to cultivated soils is toxic to many arthropod species initially and that the extent and duration of this toxicity depends on the level and frequency of application. It was found out that changes in abundance were clear in Acarina and Collembola. It could be concluded that fertilizer application always alter soil fauna population. However, organic manure increases soil fauna if added in the recommended doses. Otherwise, it would be toxic to soil organisms. On the other hand, chemical fertilizers would either increase or decrease fauna population according to many complex factors.

4. Effect of organic manures and mineral nitrogenous fertilizers on mites occurring in soybean soil:

Data in Table (5) show the relative distribution of soil mite groups as affected by type of fertilizers. Over mite groups, poultry manure had the highest number of mites (6900 indiv/ $/ \mathrm{m}^{3}$ soil), followed by pigeon refuse (6155.5 indiv) and then sheep manure (5522.2 indiv). The lowest populations of soil mites were detected in soils treated with ammonium nitrate (4522.2 indiv) and urea (4311.2 indiv).

Statistical analysis revealed significant differences in mite populations due to different types of fertilizer. However, the numbers were 
usually higher in organic manure than in mineral fertilizers. When the soil mite group is considered, Cryptostigmata usually exhibited the highest percentage as compared with the other mite groups. It comprised 40.04, 46.21, 39.29,

$48.65,36.08$ and $39.32 \%$ out of total numbers of mites recorded in sheep manure, pigeon refuse, poultry manure, ammonium nitrate, urea and control, respectively. The second rank of mite occurrence was occupied by Heterostigmata exhibiting $39.64,32.31,37.36,25.06,33.76$ and $35.09 \%$ for the abovementioned types of fertilizers, respectively. In most cases, the third rank was that of Prostigmata, as the relative occurrence ranged between 11.30 and $17.15 \%$. The fourth rank was that of Mesostigmata, with percentages ranging between 5.43 and $13.66 \%$, while the percentages of Astigmata were the least, ranging between 0.80 and $1.97 \%$.

Table (5): Mean numbers of mite groups occurring in soybean soil treated with different types of fertilizers during 2007 season.

\begin{tabular}{|c|c|c|c|c|c|c|c|c|c|c|c|c|}
\hline \multirow[b]{2}{*}{ Mite group } & \multicolumn{12}{|c|}{ Mean numbers of mite $/ \mathrm{m}^{3}$ soil } \\
\hline & \begin{tabular}{|c|} 
Sheep \\
manure
\end{tabular} & $\%$ & \begin{tabular}{|l|} 
Pigeon \\
Refuse
\end{tabular} & $\%$ & \begin{tabular}{|l|} 
Poultry \\
manure
\end{tabular} & $\%$ & $\begin{array}{c}\text { Ammonium } \\
\text { Nitrate }\end{array}$ & $\%$ & Urea & $\%$ & Control & $\%$ \\
\hline Hete & $2188.9 \mathrm{ab}$ & 39.64 & $1988.9 \mathrm{~b}$ & 32.31 & $2577.8 \mathrm{a}$ & 37.36 & $1133.3 \mathrm{c}$ & 25.06 & $1455.6 \mathrm{c}$ & 33.76 & $1477.8 \mathrm{c}$ & 35.09 \\
\hline Mesostigmata & $300.0 \mathrm{c}$ & 5.43 & $522.2 \mathrm{~b}$ & 8.48 & $722.2 \mathrm{a}$ & 10.47 & $588.9 \mathrm{~b}$ & 13.02 & $588.9 \mathrm{~b}$ & 13.66 & $311.1 \mathrm{c}$ & 7.39 \\
\hline Astigmata & $44.4 \mathrm{~b}$ & 0.80 & $77.8 \mathrm{ab}$ & 1.26 & $100.0 \mathrm{a}$ & 1.45 & $88.9 \mathrm{ab}$ & 1.97 & $66.7 \mathrm{ab}$ & 1.55 & $44.4 \mathrm{~b}$ & 1.05 \\
\hline Cryptostigmata & $2211.1 \mathrm{~b}$ & 40.04 & $2844.4 \mathrm{a}$ & 46.21 & $2711.1 \mathrm{a}$ & 39.29 & $2200 \mathrm{~b}$ & 48.65 & $1555.6 \mathrm{c}$ & 36.08 & $1655.6 \mathrm{c}$ & 39.32 \\
\hline Pro & $777.8 \mathrm{ab}$ & 14.09 & $722.2 \mathrm{ab}$ & 11.73 & $788.9 a$ & 11.43 & $511.1 \mathrm{c}$ & 11.30 & $644.4 \mathrm{~b}$ & 14.95 & $722.2 \mathrm{ab}$ & 17.15 \\
\hline Total & 5522.2 & 100 & 6155.5 & 100 & 6900 & 100 & 4522.2 & 100 & 4311.2 & 100 & 4211.1 & 100 \\
\hline
\end{tabular}

In a row, means followed by the same letter are not significantly different at the $5 \%$ level.

\section{Effect of organic manures and mineral nitrogenous fertilizers on soil content of NPK and organic matter:}

Data in Table (6) revealed that the application of the organic manures and mineral fertilizers had a significant effect on the availability of $\mathrm{N}, \mathrm{P}, \mathrm{K}$ and organic matter content. Available N, P, K and organic matter content in soil increased up to $142.52,9.04,613.0(\mathrm{ppm})$ and $3.18 \%$ for pigeon refuse $(\mathrm{N})$, sheep manure $(P, K)$ and pigeon refuse $(O M)$, respectively. It was noticed that soil available nutrients resulting from the application of organic manure were higher than the mineral treatments. The content of soil organic matter were in the order of pigeon refuse $>$ sheep manures $>$ poultry manure $>$ urea $>$ ammonium nitrate $>$ control. These results are in accordance with those of Metwally and Khamis (1998) who reported that organic manuring plays a role in increasing the $\mathrm{N}$ availability through microorganism activities, beside decreasing $\mathrm{N}$ losses by leaching and volatilization. Microflora can directly assimilate significant amounts of organic $\mathrm{N}$ compounds from plant residues and from dead biomass (Mary et al., 1996). The availability of soluble $P$ increases from additions of compost which has an effect that described as resulting from phosphoumic complexes that minimize immobilization processes, anion replacement of phosphate by humatc ions, and coating of sesquioxide particles by humus to form a cover which reduces the phosphate fixating capacity of the soil (Rechcigl, 1995). Concerning the increasing of available K after addition of composts, Tan (1993) found that humic and fulvic acids are capable of dissolving very small amounts of potassium from the soil 


\section{Saadoon, Sohair E. et al.}

minerals by chelating, complex reaction or both with released amounts of $\mathrm{K}$ being increased with time.

Table (6): Effect of application organic manures and mineral nitrogen fertilizers on the availability of NPK and organic matter content in soil.

\begin{tabular}{|c|c|c|c|c|c|c|}
\hline Macro-element & $\begin{array}{c}\text { Sheep } \\
\text { manure }\end{array}$ & $\begin{array}{c}\text { Pigeon } \\
\text { refuse }\end{array}$ & $\begin{array}{c}\text { Poultry } \\
\text { manure }\end{array}$ & $\begin{array}{c}\text { Ammonium } \\
\text { nitrate }\end{array}$ & Urea & Control \\
\hline $\mathrm{N} \mathrm{ppm}$ & $82.76 \mathrm{e}$ & $142.52 \mathrm{a}$ & $131.74 \mathrm{~b}$ & $94.13 \mathrm{~d}$ & $98.13 \mathrm{c}$ & $68.41 \mathrm{f}$ \\
\hline $\mathrm{P} \mathrm{ppm}$ & $9.04 \mathrm{a}$ & $8.06 \mathrm{~b}$ & $7.26 \mathrm{c}$ & $6.21 \mathrm{~d}$ & $6.86 \mathrm{~cd}$ & $6.35 \mathrm{~d}$ \\
\hline $\mathrm{K} \mathrm{ppm}$ & $613.0 \mathrm{a}$ & $584.18 \mathrm{~b}$ & $587.11 \mathrm{~b}$ & $549.03 \mathrm{c}$ & $551.19 \mathrm{c}$ & $517.40 \mathrm{~d}$ \\
\hline Organic matter \% & $2.95 \mathrm{ab}$ & $3.18 \mathrm{a}$ & $2.92 \mathrm{~b}$ & $1.86 \mathrm{~d}$ & $2.27 \mathrm{c}$ & $1.79 \mathrm{~d}$ \\
\hline
\end{tabular}

In a row, means followed by the same letter are not significantly different at the $5 \%$ level.

It could be concluded that using organic manure, as a substitute of mineral fertilizer, may enhance the populations of predatory arthropods while are necessary to regulate the populations of harmful pests. In addition, these organic manures increased levels of $\mathrm{N}$ and $\mathrm{K}$ in soybean plant, and sheep manure increased levels of organic matter, $\mathrm{P}$ and $\mathrm{K}$ in soybean soil. Thus, it could be recommended to use these organic manures, at least in combination with mineral fertilizers to minimize the environmental pollution coming from mineral fertilizers, and to keep the natural balance due to increase of predatory arthropod populations.

\section{REFERENCES}

Abd-Alla, F.A. (1974). Studies on soil fauna in different soils. M.Sc. Thesis, Fac., Agric., Ain shams Univ. Cairo. 147, pp.

Abd-Allah, M.A.A. (1998). Influence of sulphur and organic manures application on yield of sugar beet, subsequent crops and some chemical properties of salt affected soils. Ph.D. Thesis, Fac. of Agric., Tanta Univ.

Abo-Korah, S.M. (1977). Specific composition and ecology of cohort Tarsonemina under wheat. Ph.D. Thesis, Fac. Biol. Odessa Univ., USSR, $111 \mathrm{pp}$.

Abo-Korah, S.M.; A.A. Osman and S.E. Saadoon (1984). Effect of certain soil fertilizers on soil Acari inhabiting okra field in Menofia Governorate, Egypt. Bull. Soc. Ent. Egypt. 65: 59-64.

Abo-Korah, S.M.; H.A.S. Radwan; M.G. Elgar and S.E. Salem (1982). Response of soil Acari groups to certain fertilizers adapted in cotton fields, in Menofia Governorate, Egypt. Proc. Egypt's National Conf. Entomol. (1): 125-131.

Abou El-Khir, A.M.; M.A. El-Kammah; T.M. El-Esswi; F.I. Zein and N.I. Talha (2004). Effect of some organic manures and agrochemical amendments on quality and yield of flax and soybean crops under field conditions. J. Agric. Res., Tanta Univ., 30(3): 778-796.

Acki, J. (1973). Soil zoology, an introduction to classification and ecology of soil animals. Hokuryu-Kan, Tokyo-i-XIII+1-814 (in Jap.)

Amberger, A. (1993). Dynamics of nutrients and reactions of fertilizers applied on the environment. Proceedings of German/Egyptian/Arab Workshop in Cairo and Ismailia, Egyt. 6-17 June, pp. 41-59. 
Chapman, H.D. and P.F. Pratt (1961). Methods of analysis for soils plants and waters. Univ. of California, Div-Agric. Scin. P. 150.

Chougule, B.A.; P.M. Kotecha; R.N. Adsule and B.S. Manke (1993). Effect of fertilizer, irrigation and sowing dates on quality of wheat. J. of Maharashtra Agric. Univ., 18(2): 226-228.

Coaker, T.H. (1987). Cultural methods; the crop. IN: Burn, A.J. Coaker, T.H. and P.C. Jepson (eds), integrated pest management. Academic Press, London, pp. 69-88.

Duncan, D.B. (1955). Multiple range and multiple F-tests. Biometrics. 11: 142.

El-Badry, E.A. (1973). A comparative ecological analysis of the soil Mesostigmata (Acarina) associated with some coniferous Bavarian Forests. Z. Ang. Ent., 73: 117-128.

El-Fouly, M.M.; A.F.A. Fawzi and A.A. El-Sayed (1997). Nutritional deficiencies in cotton in Egypt. Proc. FAO. IRCRNC, Joint Meeting of the Working Groups 4 \& 3 (cotton Nutrition \& Growth Regulators) 2023. March, 1995, Cairo, Egypt, pp. 59-65.

El-Shazly, W.M.O. and M.F. El-Masri (2002). A comparative study on the effect of some organic manure and mineral nitrogen fertilizer on the leaf chemical composition, growth, earliness and yield of cotton (Giza 89 cultivar). Minufiya, J. Agric. Res. 27(6): 1325-1348.

Hamissa, M.R. and M.E. Abdel Salam (1999). Fertilizer management for cotton in Egypt. Adv. Agric. Res. Egypt, 1(1): 53-113.

Harmati, I. (1991). The grain yield of some wheat varieties from szeged as affected by fertilizer application to calcareous meadow soil. Novenytemelis, 40(5): 447-448.

Jackson, M.L. (1958). Soil chemical analysis. Prentice Hall Inc., Englewood Cliffs, New Jersey.

Khalil, M.E.A.; Nadia M. Badran and M.A.A. El-Eman (2000). Effect of different organic manures on growth and nutritional status of corn. Egypt. J. Soil Sci., 40(1-2): 245-263.

Lindquist, E.E.; B.D. Ainscough; F.V. Clulow; R.C. Funk; V.G. Marshall; H.H.J. Nesbitt; B.M. Oconner; I.M. Smith and P.R. Wilkinson (1979). 12 Acari. Men. ent. Soc. Can., 108: 252-290.

Luxton, M. (1972). Studies on the oribatid mites of a Danish wood soil. Pedobiologia, 12: 434-463.

Mar, B.; S. Recous; Darwis and D. Robin (1996). Interaction between decomposition of plants residues and nitrogen cycling in soil. Plant and Soil. 181, 71.

Metwally, Sh.M. and M.A. Khamis (1998). Comparative effects of organic and inorganic nitrogen sources applied to a sandy soil on availability of $\mathrm{N}$ and wheat yield. Egypt, J. Soil Sci., 38(1-4): 35.

Olsen, S.R.; C.V. Cale; F.S. Watanabe and L.A. Dean (1954). Estimation of available phosphorus in soil by extraction with sodium bicarbonate. USDA. Circ., 939.

Page, A.L. (ed.) (1982). Methods of soil analysis, part 2: Chemical and Microbiological properties. (2nd ed.) American, Wisconsin, USA.

Rechcigl, J.E. (1995). Soil amendments and environmental quality, CRC, Press, Inc. 


\section{Saadoon, Sohair E. et al.}

Saber, R.A. (2000). Remediation and potential environmental impacts assessments of some biosolids. Ph.D. Thesis, Fac. of Agric., Tanta Univ.

Saleh, R.S. and M.S. Tadros (1985). The effect of some foliar fertilizers on both soil arthropods and Gloduls hortulans Proc. IX Int. Colloq. Soil Zool., Moscow, USSR: 239.

Schouwenburg, J.C. Van and I. Walinge (1967). The rapid determination of phosphorus in presence of arsenic, silicon and genminium. Anal. Chem. Acta, 37: 271-274.

Snell, F.D. and C.T. Snell (1967). Colorimatric methods of analysis. O. Van Nostrand Company, Inc.: 551-552.

Talha, N.I.A. (2003). Potential effects of bio-remedia management of some biosolid wastes on quality of soil and some field crops. Ph.D. Thesis, Fac. of Agric., Kafr El-Sheikh, Tanta Univ.

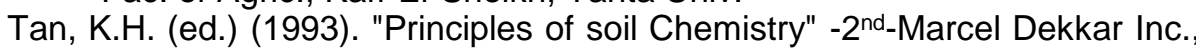
New York, USA.

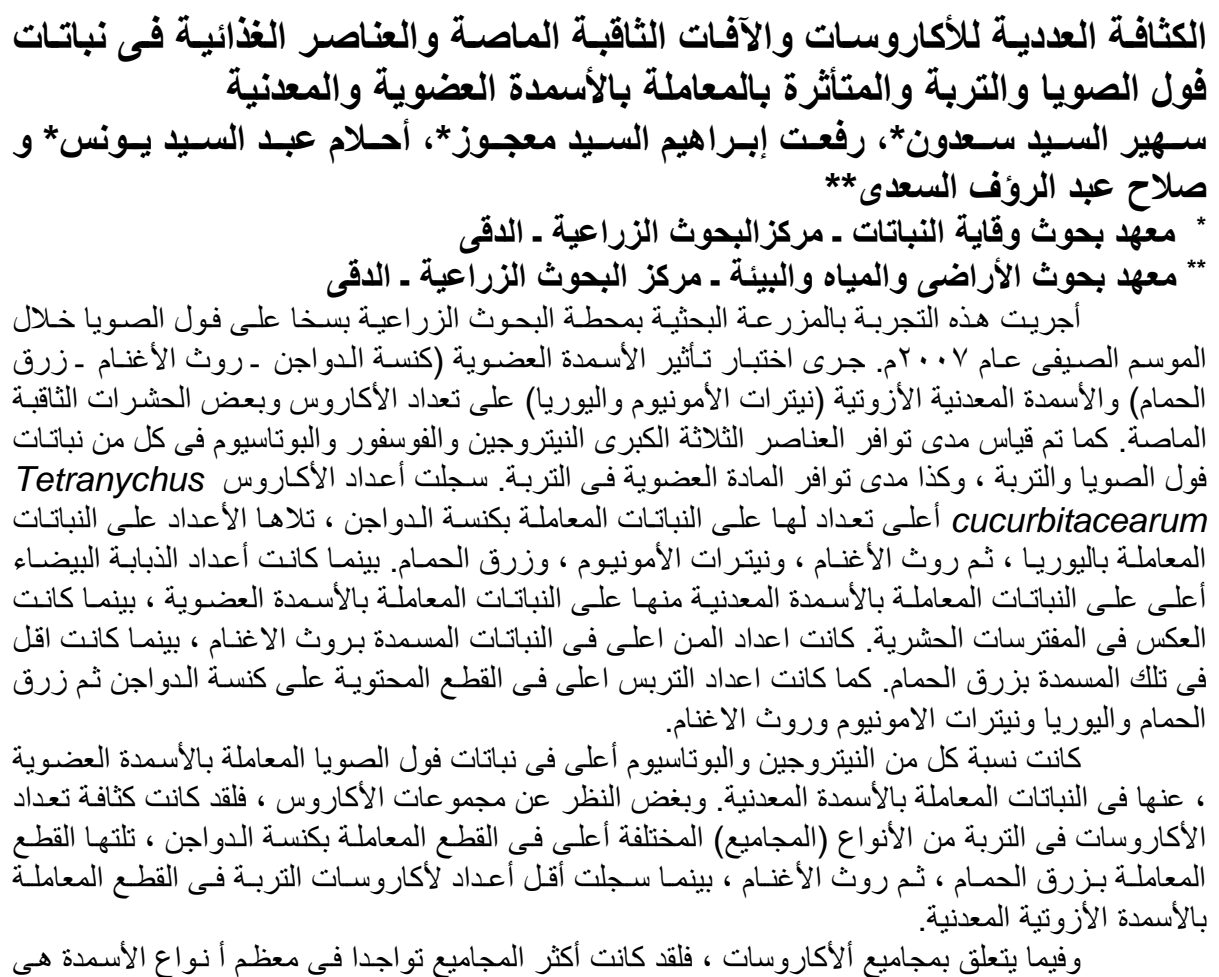

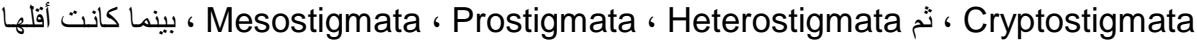
Astigmata أعلى نسب الفوسفور والبوتاسيوم فى التربة المعاملة بروث الأغنام. 